\title{
Comparison the Adsorption Capacity of Ukrainian Tuff and Basalt with Zeolite-Manganese Removal from Water Solution
}

\author{
Yuliia Trach', Marta Tytkowska-Owerko², Lidia Reczek², Magdalena M. Michel²* \\ 1 Department of Water Supply, Water Disposal and Drilling Engineering, National University of Water and \\ Environmental Engineering, Soborna 11, 33028 Rivne, Ukraine \\ 2 Institute of Environmental Engineering, Warsaw University of Life Sciences-SGGW, Nowoursynowska 166, \\ 02-787 Warsaw, Poland \\ * Corresponding author's e-mail: magdalena_michel@sggw.edu.pl
}

\begin{abstract}
Manganese is an undesirable element in tap water but is common in the groundwater. Several methods can be used for manganese removal, including adsorption. Mined rocks are commonly evaluated as adsorbents and it was the objective of this paper - to investigate the Ukrainian volcanic tuff and basaltic rock from the Ivanodolinsky quarry and compare it with Ukrainian zeolite as well as with literature data. The research was based on equilibrated batch tests at a temperature of $10^{\circ} \mathrm{C}$ and slightly acidic $\mathrm{pH}$. The data were treated using Langmuir and Freundlich models in the linear form. The results indicated the spontaneous and favourable adsorption of manganese. The volcanic tuff was characterized by the highest adsorption capacity, twice higher than basalt and zeolite. The heterogeneity of the active adsorption sites on the tuff was also greater and resulted from the diversity of the mineral composition. Considering the literature data, the properties of tuff are worth further research.
\end{abstract}

Keywords: water treatment, natural sorbents, ion exchange minerals, saponite, hematite, andesine.

\section{INTRODUCTION}

The presence of manganese in the water environment can be caused by the anthropogenic pressure; however, manganese can also be a natural component. Manganese is especially common in groundwater and when water is collected for the supply purposes, manganese is removed for the operational and sanitary reasons [Latterman 1999; Kowal and ŚwiderskaBróż 2007]. Usually, manganese is removed as a result of homogeneous or heterogeneous oxidation to insoluble oxyhydroxides being mechanically separated on filtering bed [Vries et al. 2017]. Various methods are used for the oxidation: adding chemical oxidants such as potassium permanganate or sodium hypochlorite; aerating and adding alkali; aerating and using beds containing manganese oxides as catalysts, sometimes being of biogenic origin [Tekerlekopoulou et al. 2013].
Another solution for the removal of heavy or transition metals from water is the use of sorption materials. The metals dissociated in water can be adsorbed by various materials, such as activated carbon, resins, mineral sorbents or biosorbents [Sen Gupta and Bhattacharyya 2011; Jiang et al. 2015; Renu et al. 2017]. Activated carbon and resins are highly effective sorbents, but their production costs are also high [Cegłowski and Schroeder 2015]. Low cost materials for heavy and transition metals removal are biosorbents or natural minerals. Mined rocks are characterized by a varied mineral composition, which significantly determines their adsorption properties. For this reason, their suitability is determined in technological research.

The adsorption properties of materials are assessed using various factors, which can be determined under equilibrium conditions. In order to predict adsorption, two-parameter isotherms are 
used, as well as more-parameter models. The constants of isotherm models give information about the nature of adsorption process and interactions between adsorbent and removing particles. The primary parameter is the adsorption capacity, which is used by many authors to compare materials in terms of the effectiveness of their use in the adsorption process [Hamdaoui and Naffrechoux 2007; Gupta et al. 2009; Renu et al. 2017; Ugwu and Igbokwe 2019].

The aim was to determine the adsorption properties of the Ukrainian volcanic tuff and basaltic rock in manganese solution and to compare them with the results obtained for Ukrainian zeolite as well as with the literature data. These studies are a part of the research on the use of natural mineral adsorbents to remove metals from water, in this case manganese.

\section{MATERIALS AND METHODS}

The investigated rock materials were the volcanic tuff (T) and basalt (B) from the Ivanodolinsky quarry (Rivne region, Ukraine) as well as the zeolite $(\mathrm{Z})$ from the Sokirnitskoe deposit (Zakarpattia region, Ukraine). The tuff mainly consists of saponite $(58 \% \mathrm{w} / \mathrm{w})$ and a smaller amount of quartz (22\%), hematite $(17 \%)$ and analcime $(3 \%)$, whereas the composition of basaltic rock is dominated by andesine (93\%) with an admixture of saponite (7\%) [Melnychuk et al. 2018]. The main component of zeolite is clinoptilolite (70-80\%) [Rogov 2009]. The rocks were used in the natural form without thermal treatment, prepared only by grinding and sieving $(<0.1 \mathrm{~mm})$.

The adsorption equilibrium experiment was carried out in conical flasks by shaking the rock materials in $\mathrm{Mn}$-solutions at $10^{\circ} \mathrm{C}$ during $24 \mathrm{~h}$. The Mn-solutions were obtained by dissolution of manganese(II) chloride tetrahydrate (pure reagent by Chempur) in distilled water. The solutions were characterized by the Mn concentration in the range $2-17 \mathrm{mg} / \mathrm{L}$ and $\mathrm{pH} 5.96 \pm 0.08$. Two types of experimental series differed in the ratio of rock mass to the solution volume: $1 \mathrm{~g} / 1 \mathrm{~L}$ and $2 \mathrm{~g} / 1 \mathrm{~L}$. After shaking, the solutions were separated from the mixtures by centrifugation in the time 7 minutes at $1500 \mathrm{rpm}$. The Mn concentration in solutions before and after adsorption was measured by means of the AAS technique using a PG Instruments spectrometer. In the solutions, $\mathrm{pH}$ was also measured using a gel electrode and Hach HQ40D-Multimeter.

Equilibrium adsorption capacity $q_{e}(\mathrm{mg} / \mathrm{g})$ was calculated according to the equation:

$$
q_{e}=\frac{\left(C_{0}-C_{e}\right) \cdot V}{m}
$$

where: $C_{0}(\mathrm{mg} / \mathrm{L})$ and $C_{e}(\mathrm{mg} / \mathrm{L})$ are the $\mathrm{Mn}$ concentrations in solution before adsorption and at equilibrium, respectively, $V(\mathrm{~L})$ is the volume of solution and $m(g)$ is the mass of rock sample.

The data obtained from the adsorption experiment were treated using the Langmuir and Freundlich models. Linear regression was used; the applied isotherm equations are presented in the Table 1. The fit of the models to the experimental data was validated using coefficient of determination $\left(R^{2}\right)$, chi-square statistic $\left(\chi^{2}\right)$ and mean absolute percentage error (MAPE). In chi-square test 2-tailed significance level $(p)$ was calculated for 7 degrees of freedom.

\section{RESULTS AND DISCUSSION}

The results of fitting isotherm models of $\mathrm{Mn}$ adsorption at equilibrium on the tested materials are shown in Table 2 and in Figures 1-3. On the basis of $R^{2}, \chi^{2}$ and MAPE values, it has been determined that the adsorption of Mn onto volcanic tuff and basalt is very well described by both the

Table 1. Isotherm models applied to data treatment. Equations [Hamdaoui and Naffrechoux 2007].

\begin{tabular}{|c|c|c|}
\hline Equation No. & Isotherm equation & Coordinates \\
\hline \multicolumn{3}{|c|}{ Linearized form of Langmuir equation } \\
\hline$(2)$ & $\frac{C_{\theta}}{q_{\theta}}=\frac{1}{q_{m}} C_{\theta}+\frac{1}{b q_{m}}$ & $C_{\theta} / q_{\theta}$ vs. $C_{\theta}$ \\
\hline \multicolumn{3}{|c|}{ Linearized form of Freundlich equation } \\
\hline (3) & $\ln q_{\theta}=\ln K_{F}+\frac{1}{n} \ln C_{\theta}$ vs. $\ln C_{\theta}$ \\
\hline \multicolumn{2}{|c|}{ where $q_{m}$ and $b$ are the Langmuir isotherm constants, whereas $K_{F}$ and $n$ are the Freundlich isotherm constants } \\
\hline
\end{tabular}


Langmuir and Freundlich models. That indicates the monolayer adsorption as well as surface heterogeneity. However, the values of coefficient of determination and other error factors suggest that the adsorption on the volcanic tuff is slightly better described by the Freundlich model $(\mathrm{F} \geq \mathrm{L})$, whereas the Langmuir model slightly better predicts the adsorption on basaltic rock $(\mathrm{L} \geq \mathrm{F})$. This may be related to the greater heterogeneity of the active adsorption sites on the tuff showing a greater variety in mineral composition than basalt. The results of Mn adsorption on the reference material (zeolite) is definitely fitted by Langmuir model $(\mathrm{L}>>\mathrm{F})$ because of the adsorption by ion exchange occurs. This mechanism is commonly known [Rhodes 2010; Taffarel and Rubio 2010; Margeta et al. 2013]. The above consideration indicates that the properties of tuff and basalt can be discussed on the basis of the Langmuir and Freundlich constants, whereas zeolite - only by using Langmuir model constants.

Among the tested materials, the highest maximum adsorption capacity $\left(q_{m}\right)$ has the tuff contained saponite and hematite, minerals characterized by significant adsorption properties relative to heavy and transition metals and radionuclides [Shuibo et al. 2009; Petra et al. 2017; Zhou et al. 2019; Gunawardhana et al. 2020]. It was twice higher than for zeolite rich in clinoptilolite and basalt consisting mainly of andesine. The ratio of adsorbent mass to the solution volume is significant in the case of tuff and zeolite, higher maximum capacities were achieved using ratio $1 \mathrm{~g} / 1 \mathrm{~L}$, not $2 \mathrm{~g} / 1 \mathrm{~L}$. This is important when designing adsorption systems.

Comparing the obtained results with the results of other studies on natural mineral adsorbents (Table 3), it can be concluded that volcanic tuff is characterized by high adsorption capacity. This comparison required an expression of the adsorption capacity in mmoles $\cdot \mathrm{g}^{-1}$ due to the study of various elements. The adsorption capacity of basaltic rock and zeolite can be described as an intermediate. It should be noted that in the presented study, the temperature was much lower than in other studies, since the groundwater temperature was simulated. Our previous study indicated that the $\mathrm{Mn}$ adsorption rate and removal efficiency do not change at temperature $10-25^{\circ} \mathrm{C}$ [Reczek et al. 2020]. However, differences in experimental conditions and material preparation may be the reason for obtaining lower adsorption capacity of the Sokirnitskoe zeolite (clinoptilolite) than in paper of Korablew et al. [2017]. The maximal adsorption capacity of manganese dioxide modified siliceous rock used for groundwater treatment is $1.25 \mathrm{mg} \cdot \mathrm{g}^{-1}$ [Michel and Kiedryńska 2012] several times lower than the capacities of volcanic tuff and basaltic rock. In this regard, the properties of volcanic tuff seem to be promising.

Another important factor affecting the adsorption results is $\mathrm{pH}$ of solution. In the present study, the $\mathrm{MnCl}_{2}$ solution was slightly acidic ( $\mathrm{pH} 5.96 \pm$ 0.08 ) which corresponds well with slightly acidic characteristics of ground water. During $\mathrm{Mn}$ adsorption, the $\mathrm{pH}$ grew and at equilibrium the $\mathrm{pH}$ increased on average by $0.54 \pm 0.09$ in tuff and

Table 2. Parameters of the Langmuir and Freundlich isotherm for manganese adsorption on volcanic tuff, basalt and zeolite.

\begin{tabular}{|c|c|c|c|c|c|c|c|}
\hline \multirow{2}{*}{\multicolumn{2}{|c|}{ Parameters of models }} & \multicolumn{2}{|c|}{ Volcanic tuff } & \multicolumn{2}{|c|}{ Basalt } & \multicolumn{2}{|c|}{ Zeolite } \\
\hline & & $1 \mathrm{~g} / 1 \mathrm{~L}$ & $2 \mathrm{~g} / 1 \mathrm{~L}$ & $1 \mathrm{~g} / 1 \mathrm{~L}$ & $2 g / 1 L$ & $1 \mathrm{~g} / 1 \mathrm{~L}$ & $2 g / 1 L$ \\
\hline \multicolumn{8}{|c|}{ Langmuir isotherm } \\
\hline \multirow{6}{*}{ Eq. (2) } & $q_{m}, \mathrm{mg} \mathrm{g}^{-1}$ & 8.41 & 5.99 & 3.66 & 3.20 & 4.13 & 2.18 \\
\hline & $b, \mathrm{dm}^{3} \mathrm{mg}^{-1}$ & 0.500 & 0.745 & 0.207 & 0.170 & 0.364 & 0.787 \\
\hline & $R^{2}$ & 0.9802 & 0.9718 & 0.9163 & 0.9417 & 0.9310 & 0.9651 \\
\hline & $x^{2}$ & 0.2023 & 0.4837 & 0.1259 & 0.0887 & 0.1814 & 0.3839 \\
\hline & $p$ & $>0.999$ & $>0.999$ & $>0.999$ & $>0.999$ & $>0.999$ & $>0.999$ \\
\hline & MAPE & 0.0598 & 0.1077 & 0.0660 & 0.0689 & 0.0950 & 0.1769 \\
\hline \multicolumn{8}{|c|}{ Freundlich isotherm } \\
\hline \multirow{6}{*}{ Eq. (3) } & $K_{F}, \mathrm{mg}^{1-1 / n} \mathrm{~L}^{1 / n} \mathrm{~g}^{-1}$ & 2.78 & 2.35 & 0.762 & 0.623 & 1.27 & 0.908 \\
\hline & $\mathrm{n},-$ & 2.27 & 2.31 & 1.96 & 1.96 & 2.79 & 2.77 \\
\hline & $R^{2}$ & 0.9769 & 0.9925 & 0.9049 & 0.9147 & 0.6833 & 0.5589 \\
\hline & $x^{2}$ & 0.1297 & 0.0311 & 0.1845 & 0.1702 & 0.7894 & 0.7181 \\
\hline & $p$ & $>0.999$ & $>0.999$ & $>0.999$ & $>0.999$ & $>0.998$ & $>0.998$ \\
\hline & MAPE & 0.0512 & 0.0263 & 0.1002 & 0.1015 & 0.1921 & 0.2344 \\
\hline
\end{tabular}




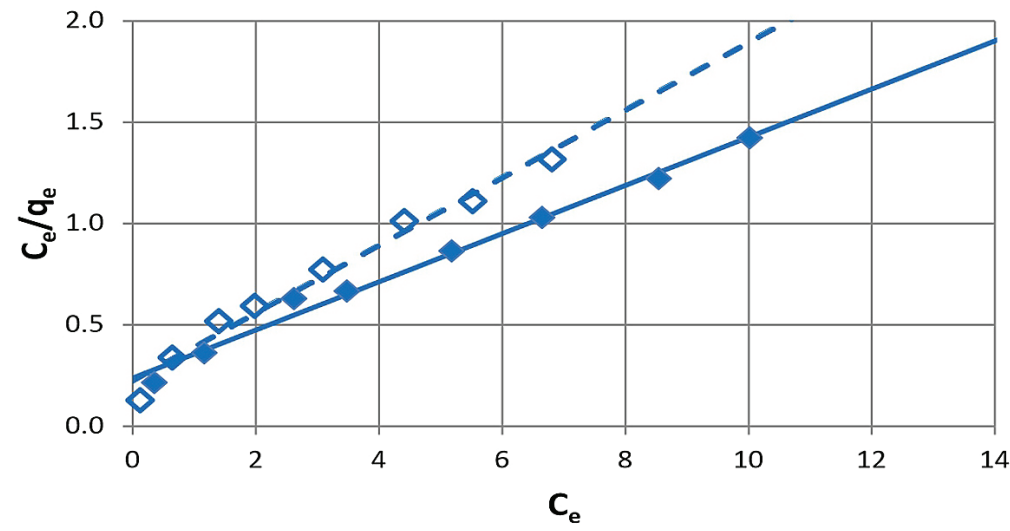

- T $1 \mathrm{~g} / 1 \mathrm{~L}$ experimental data $\longrightarrow \mathrm{T} 1 \mathrm{~g} / 1 \mathrm{~L}$ model

- T 2g/1L experimental data - - T 2g/1L model

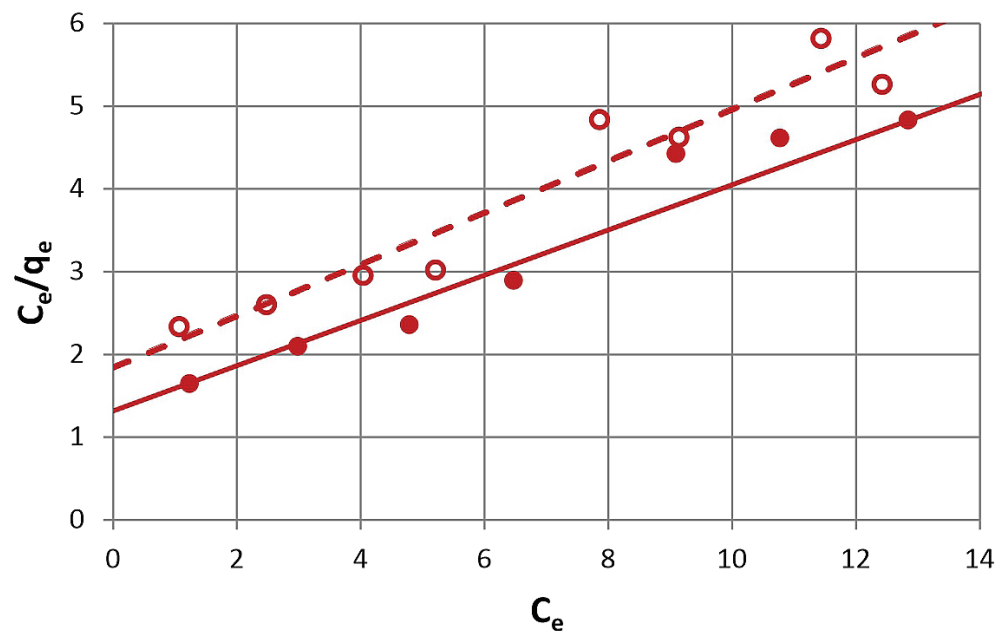

- $\mathrm{B} 1 \mathrm{~g} / 1 \mathrm{~L}$ experimental data $\mathrm{B} 1 \mathrm{~g} / 1 \mathrm{~L}$ model

- $\mathrm{B} 2 \mathrm{~g} / 1 \mathrm{~L}$ experimental data - - B $2 \mathrm{~g} / 1 \mathrm{~L}$ model

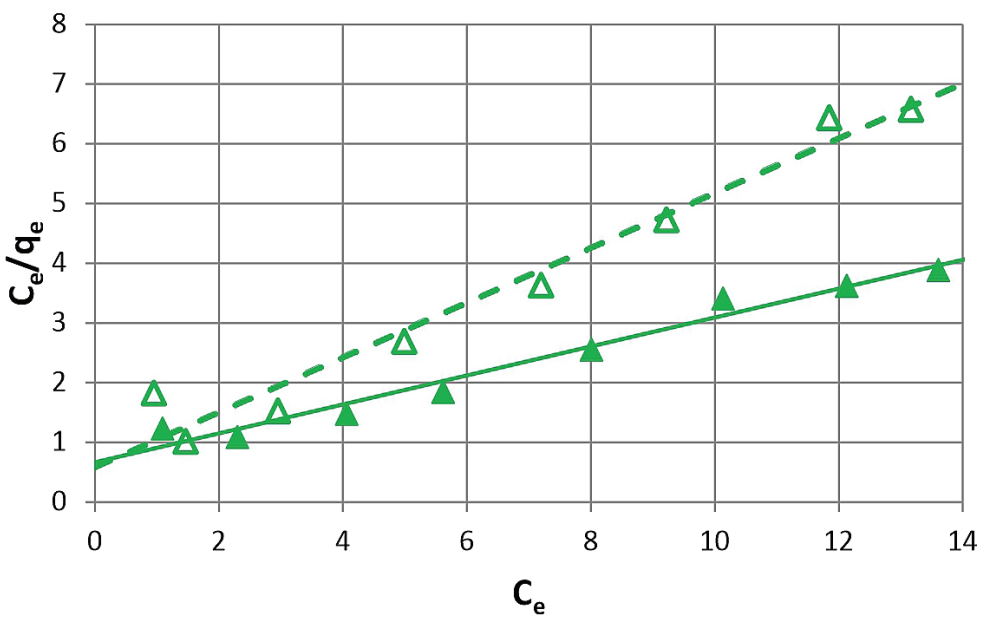

$\Delta \quad \mathrm{Z} 1 \mathrm{~g} / 1 \mathrm{~L}$ experimental data $-\mathrm{Z} \mathrm{g} / 1 \mathrm{~L}$ model

$\Delta \quad \mathrm{Z} 2 \mathrm{~g} / 1 \mathrm{~L}$ experimental data $--\mathrm{Z} 2 \mathrm{~g} / 1 \mathrm{~L}$ model

Figure 1. Langmuir isotherms for Mn adsorption onto volcanic tuff (a), basalt (b) and zeolite (c) investigated in two proportions of rock mass to the solution volume: $1 \mathrm{~g} / 1 \mathrm{~L}$ and $2 \mathrm{~g} / 1 \mathrm{~L}$. 


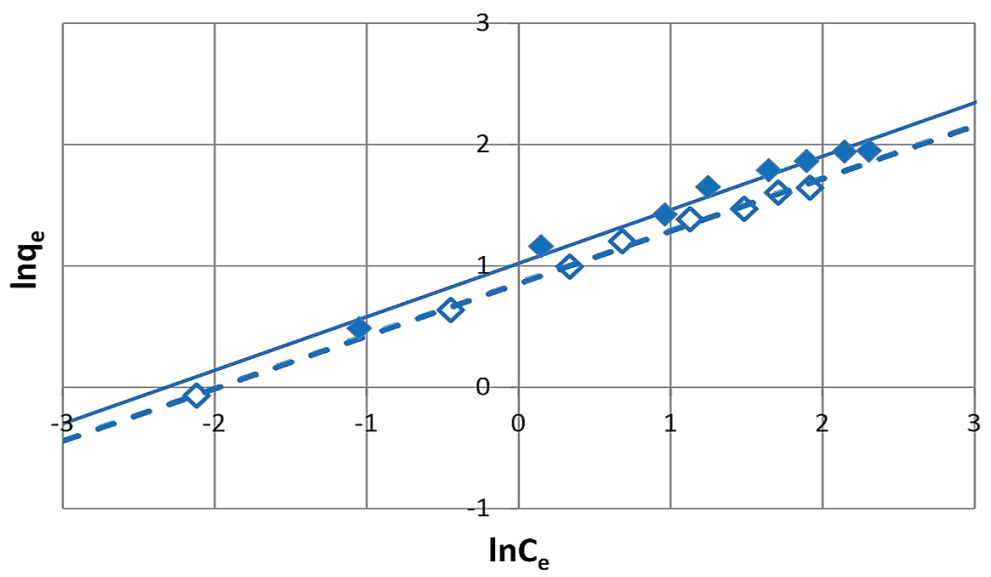

- T 1g/1L experimental data — T $1 \mathrm{~g} / 1 \mathrm{~L}$ model

$\diamond \mathrm{T} 2 \mathrm{~g} / 1 \mathrm{~L}$ experimental data - - T $2 \mathrm{~g} / 1 \mathrm{~L}$ model

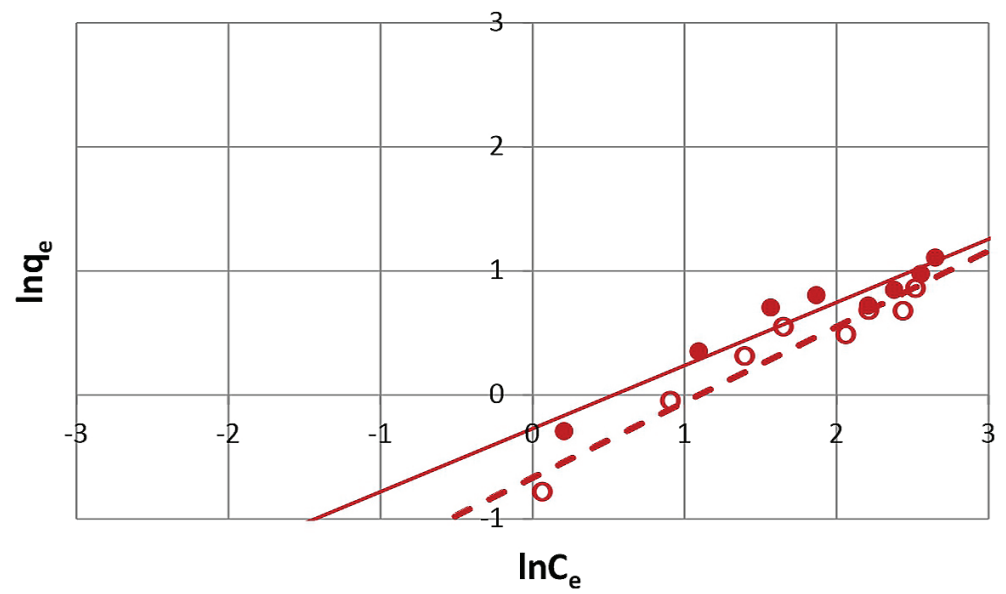

- B $1 \mathrm{~g} / 1 \mathrm{~L}$ experimental data — $\mathrm{B} 1 \mathrm{~g} / 1 \mathrm{~L}$ model

- B $2 \mathrm{~g} / 1 \mathrm{~L}$ experimental data $=-$ B $2 \mathrm{~g} / 1 \mathrm{~L}$ model

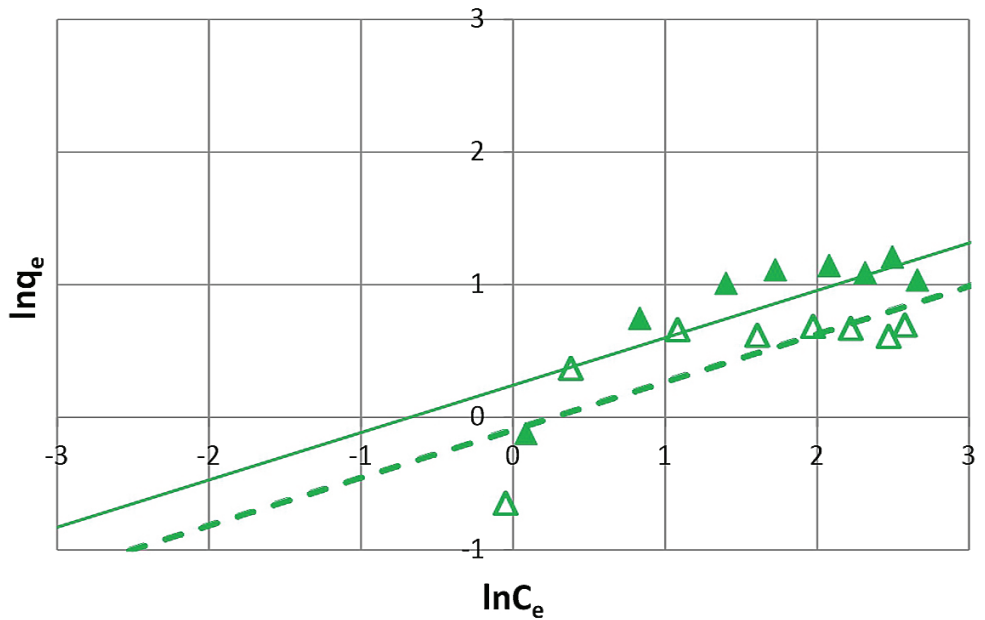

- Z 1g/1L experimental data $\longrightarrow$ Z $1 \mathrm{~g} / 1 \mathrm{~L}$ model

$\Delta \mathrm{Z} 2 \mathrm{~g} / 1 \mathrm{~L}$ experimental data $-\mathrm{Z} 2 \mathrm{~g} / 1 \mathrm{~L}$ model

Figure 2. Freundlich isotherms for Mn adsorption onto volcanic tuff (a), basalt (b) and zeolite

(c) investigated in two proportions of rock mass to the solution volume: $1 \mathrm{~g} / 1 \mathrm{~L}$ and $2 \mathrm{~g} / 1 \mathrm{~L}$. 

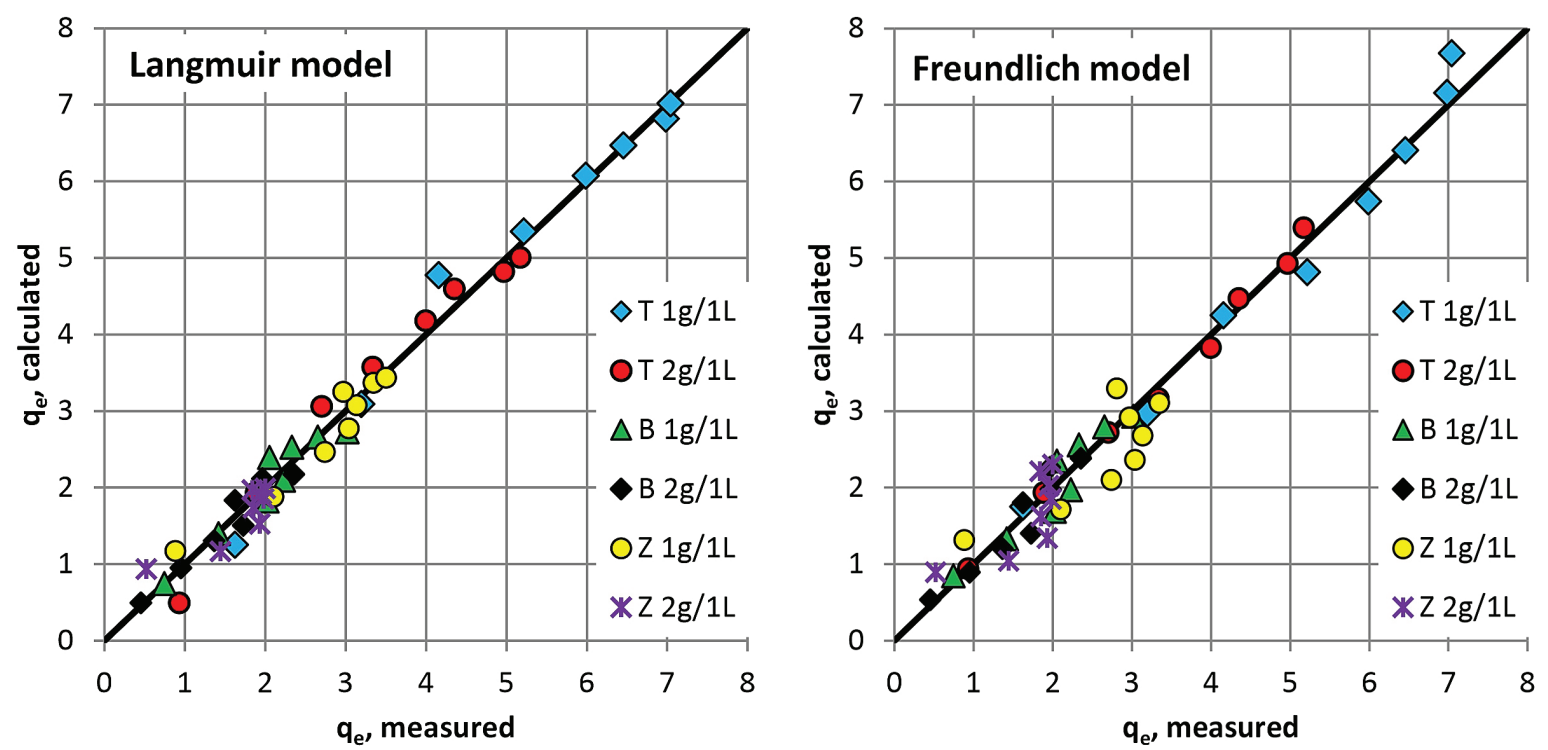

Figure 3. Calculated vs. measured equilibrium adsorption capacity $\left(\mathrm{q}_{\mathrm{e}}\right)$ of analysed materials using Langmuir and Freundlich models.

by $0.55 \pm 0.12$ in basalt batch samples. Zeolite changed the $\mathrm{pH}$ of the solution more significantly, increasing it by a value of $0.98 \pm 0.12$. This may indicate an ion exchange with alkali and alkaline earth metal cations present in the investigated mineral materials. However, it can be generalized that at slightly acidic $\mathrm{pH}$, close to neutral, the removal of manganese on volcanic tuff and basalt gives good results. Although the $\mathrm{pH}$ of the solution was below $\mathrm{pH}_{\mathrm{PZC}}$ of the materials (volcanic tuff $\mathrm{pH}_{\mathrm{PZC}}=8.9$ and basalt $\left.\mathrm{pH}_{\mathrm{PZC}}=8.5\right) \mathrm{Mn}$ removal is not inhibited by electrostatic repulsion [Reczek et al. 2020].

Basalt has the highest affinity for Mn represented by the lowest value of the Langmuir's $b$ parameter. Importantly, increasing the concentration of tuff and zeolite from $1 \mathrm{~g} / 1 \mathrm{~L}$ to $2 \mathrm{~g} / 1 \mathrm{~L}$ decreased its affinity for Mn, represented by higher $b$ values. If it is assumed that good adsorbent is characterized by high $q_{m}$ and low $b$ values of constants in Langmuir model, then it is preferable to use tuff and zeolites in the ratio $1 \mathrm{~g} / 1 \mathrm{~L}$. On

Table 3. Comparison of equilibrium adsorption capacities of research materials with results obtained by other authors

\begin{tabular}{|c|c|c|c|c|c|}
\hline \multirow{2}{*}{ Adsorbent } & \multirow{2}{*}{$\begin{array}{l}\text { Removed } \\
\text { element }\end{array}$} & \multicolumn{2}{|c|}{ Maximum adsorption capacity } & \multirow{2}{*}{ Conditions } & \multirow{2}{*}{ Reference } \\
\hline & & $\mathrm{mg} \mathrm{g}^{-1}$ & $\mathrm{mmol} \mathrm{g}^{-1}$ & & \\
\hline $\begin{array}{l}\text { Ethiopian pumice } \\
\text { Ethiopian scoria }\end{array}$ & $\mathrm{Cd}$ & $\begin{array}{l}0.0038 \\
0.0022\end{array}$ & $\begin{array}{l}0.00003 \\
0.00002\end{array}$ & $\begin{array}{c}\text { T } 24-25^{\circ} \mathrm{C} \\
\mathrm{pH} 5.0\end{array}$ & $\begin{array}{l}\text { [Alemayehu and } \\
\text { Lennartz 2009] }\end{array}$ \\
\hline $\begin{array}{l}\text { Ethiopian pumice } \\
\text { Ethiopian scoria }\end{array}$ & $\mathrm{Ni}$ & $\begin{array}{l}1.187 \\
0.980\end{array}$ & $\begin{array}{l}0.0202 \\
0.0167\end{array}$ & $\begin{array}{c}\mathrm{T} 24.9^{\circ} \mathrm{C} \\
\mathrm{pH} 5.0\end{array}$ & $\begin{array}{l}\text { [Alemayehu and } \\
\text { Lennartz 2010] }\end{array}$ \\
\hline Rwandan volcanic rock & $\begin{array}{l}\mathrm{Cd} \\
\mathrm{Cu} \\
\mathrm{Pb} \\
\mathrm{Zn}\end{array}$ & $\begin{array}{c}6.29 \\
10.87 \\
9.52 \\
4.46 \\
\end{array}$ & $\begin{array}{l}0.0560 \\
0.1710 \\
0.0459 \\
0.0682\end{array}$ & $\begin{array}{l}\mathrm{T} 25^{\circ} \mathrm{C} \\
\mathrm{pH} 6.0\end{array}$ & [Sekomo et al. 2012] \\
\hline $\begin{array}{l}\text { Polymer synthetized from } \\
\text { volcanic tuff }\end{array}$ & $\mathrm{Zn}$ & 14.7 & 0.2248 & $\begin{array}{c}\mathrm{T} 25^{\circ} \mathrm{C} \\
\mathrm{pH} 7\end{array}$ & [Al-Zboon et al. 2016] \\
\hline Korean scoria & $\begin{array}{l}\mathrm{Cd} \\
\mathrm{Cu} \\
\mathrm{Pb} \\
\mathrm{Zn}\end{array}$ & $\begin{array}{l}2.42 \\
1.77 \\
6.94 \\
1.48 \\
\end{array}$ & $\begin{array}{l}0.0215 \\
0.0278 \\
0.0335 \\
0.0227\end{array}$ & $\begin{array}{l}\mathrm{T} 25^{\circ} \mathrm{C} \\
\mathrm{pH} 5.0\end{array}$ & [Kwon et al. 2010] \\
\hline Ukrainian clinoptilolite & $\mathrm{Mn}$ & 12.0 & 0.2184 & $\begin{array}{c}\mathrm{T} 20^{\circ} \mathrm{C} \\
\mathrm{pH} \text { no data }\end{array}$ & [Korablev et al. 2017] \\
\hline $\begin{array}{l}\text { Ukrainian volcanic tuff } \\
\text { Ukrainian basaltic rock } \\
\text { Ukrainian zeolite }\end{array}$ & $\mathrm{Mn}$ & $\begin{array}{l}8.41 \\
3.66 \\
4.13\end{array}$ & $\begin{array}{l}0.1531 \\
0.0666 \\
0.0752\end{array}$ & $\begin{array}{l}\mathrm{T} 10^{\circ} \mathrm{C} \\
\mathrm{pH} 6.0\end{array}$ & present study \\
\hline
\end{tabular}


the basis of the values of the $n$ parameter in the Freundlich model, it can be concluded that $\mathrm{Mn}$ adsorption is more spontaneous on the tuff than on the basaltic rock. However, the differences are rather small and $n$ is close to 2, the limit value between moderately difficult and good adsorption properties of material [Treybal 1981].

On the basis of the $b$ parameter values from Langmuir model expressed in $\mathrm{L}$ mmole $^{-1}$ the Gibb's free energy change $\left(\Delta G^{\circ}\right)$ was calculated as follows:

$$
\Delta G^{\circ}=-R T \ln b
$$

where: $R$ - universal gas constant $\left(\mathrm{J} \cdot \mathrm{mol}^{-1} \cdot \mathrm{K}^{-1}\right)$, $T$ - absolute temperature (K).

The results obtained in $\mathrm{kJ} \cdot \mathrm{mole}^{-1}$ are: -7.80 (T 1g/1L), -8.73 (T 2g/1L), -5.72 (B 1g/1L), -5.26 (B 2g/1L), $-7.05(\mathrm{Z} 1 \mathrm{~g} / 1 \mathrm{~L}),-8.86(\mathrm{Z} 2 \mathrm{~g} / 1 \mathrm{~L})$. The values of $\Delta G^{\circ}$ are negative, so it can be concluded that the adsorption of Mn onto raw volcanic tuff, basaltic rock and zeolite occurs spontaneously at $10^{\circ} \mathrm{C}$. It is important when the adsorption process is used to purify the cold groundwater.

\section{CONCLUSIONS}

The volcanic tuff and basalt from the Ivanodolinsky quarry in Ukraine effectively adsorbed manganese from the water solution. Adsorption occurred spontaneously at $10^{\circ} \mathrm{C}$ and in slightly acidic $\mathrm{pH}$. There are beneficial conditions when the material is planned to be used in groundwater treatment line.

The adsorption of manganese on the volcanic tuff was slightly better described by the Freundlich model $(\mathrm{F} \geq \mathrm{L})$, whereas the Langmuir model slightly better predicted the adsorption on basaltic rock $(\mathrm{L} \geq \mathrm{F})$ and definitely on the zeolite $(\mathrm{L}>>\mathrm{F})$. This may be related to the greater heterogeneity of the active adsorption sites on the tuff showing a greater variety in mineral composition than basalt and zeolite.

The tuff was characterized by the highest adsorption capacity - twice higher than basalt from the same quarry and zeolite, the reference material. The comparison with other natural mineral adsorbents classifies tuff by high adsorption capacity and basalt by intermediate. The results obtained are promising for further research.

\section{Acknowledgments}

We acknowledge Alina Kiedryńska for her help in editing the English version of the article.

\section{REFERENCES}

1. Al-Zboon K.K., Al-Smadi B.M., Al-Khawaldh S. 2016. Natural Volcanic Tuff-Based Geopolymer for Zn Removal: Adsorption Isotherm, Kinetic, and Thermodynamic Study. Water Air Soil Pollut 227, 248. https://doi.org/10.1007/s11270-016-2937-5

2. Alemayehu E., Lennartz B. 2009. Virgin volcanic rocks: kinetics and equilibrium studies for the adsorption of cadmium from water. J Hazard Mater, 169, 395-401. doi:10.1016/j.jhazmat.2009.03.109.

3. Alemayehu E., Lennartz B. 2010. Adsorptive removal of nickel from water using volcanic rocks. Appl Geochem, 25, 1596-1602. doi:10.1016/j. apgeochem.2010.08.009

4. Cegłowski M., Schroeder G. 2015. Preparation of porous resin with Schiff base chelating groups for removal of heavy metal ions from aqueous solutions. Chem. Eng. J., 263, 402-411. doi:10.1016/j. cej.2014.11.047

5. Gunawardhana B.P.N., Gunathilake C.A., Dayananda K.E.D.Y.T., Dissanayake D.M.S.N., Mantilaka M.M.M.G.P.G., Kalpage C.S., Rathnayake R.M.L.D., Rajapakse R.M.G., Manchanda A.S., Etampawala T.N.B., Weerasekara B.G.N.D., Fernando P.N.K., Dassanayake R.S. 2020. Synthesis of Hematite Nanodiscs from Natural Laterites and Investigating Their Adsorption Capability of Removing $\mathrm{Ni}^{2+}$ and $\mathrm{Cd}^{2+}$ Ions from Aqueous Solutions. J. Compos. Sci., 4, 57. doi.org/10.3390/jcs4020057

6. Gupta S., Kumar D., Gaur J.P., 2009. Kinetic and isotherm modeling of lead(II) sorption onto some waste plant materials. Chemical Engineering Journal 148, 226-233. doi.org/10.1016/j.cej.2008.08.019

7. Hamdaoui O., Naffrechoux E. 2007. Modeling of adsorption isotherms of phenol and chlorophenols onto granular activated carbon. Part I. Two-parameter models and equations allowing determination of thermodynamic parameters. Journal of Hazardous Materials 147(1-2), 381-94. doi:10.1016/j. jhazmat.2007.01.021

8. Jiang J., Ma X., Xu L., Wang L., Liu G., Xu Q., Lu J., Zhang Y. 2015. Applications of chelating resin for heavy metal removal from wastewater. e-Polymers, 15(3), 161-167. doi.org/10.1515/epoly-2014-0192

9. Korablev V. V., Chechevichkin A. V., Boricheva I. K., Samonin V. V. 2017. Structure and morphological properties of clinoptilolite modified by manganese dioxide. St. Petersburg Polytechnical University Journal: Physics and Mathematics 3, 63-70. doi. 
org/10.1016/j.spjpm.2017.03.001

10. Kowal A.L., Świderska-Bróż M. 2007. Water treatment. Wydawnictwo Naukowe PWN, Warsaw, Poland. (in Polish)

11. Kwon J. S., Yun S. T., Lee J. H., Kim S. O., Jo, H. Y. 2010. Removal of divalent heavy metals $(\mathrm{Cd}$, $\mathrm{Cu}, \mathrm{Pb}$, and $\mathrm{Zn}$ ) and arsenic(III) from aqueous solutions using scoria: Kinetics and equilibria of sorption. Journal of Hazardous Materials, 174(1-3), 307-313. doi.org/10.1016/j.jhazmat.2009.09.052

12. Letterman R.D. 1999. Water Quality and Treatment: A Handbook of Community Water Supplies. American Water Works Association. McGraw-Hill, New York, NY, USA.

13. Margeta K., Zabukovec Logar N., Šiljeg M., Farkaš A. 2013. Natural zeolites in water treatment - how effective is their use. Chapter 5 in Water treatment. Intech Open. http://dx.doi.org/10.5772/50738

14. Melnychuk V., Trach Y., Kosinov V., Michel M., Reczek L. 2018. Research of the mineral complex and opportunities using basalts and tuffs of Ivandodolinsky quarry of the Rivne region in water treatment. Проблеми водопостачання, водовідведення та гідравліки, 30, 36-47. doi:10.32347/2524-0021 $.2018 .30 .36-47$

15. Michel M.M., Kiedryńska L. 2012. Usuwanie manganu(II) na chalcedonicie modyfikowanym tlenkiem manganu(IV). Przem. Chem., 91, 1416-1419.

16. Petra L., Billik P., Melichová Z., Komadel P. 2017. Mechanochemically activated saponite as materials for $\mathrm{Cu}^{2+}$ and $\mathrm{Ni}^{2+}$ removal from aqueous solutions. Applied Clay Science 143, 22-28. doi. org/10.1016/j.clay.2017.03.012

17. Reczek L., Michel M.M., Trach Y., Siwiec T., Tytkowska-Owerko M. 2020. The kinetics of manganese sorption on Ukrainian tuff and basalt-Order and diffusion models analysis. Minerals 10, 1065. doi.org/10.3390/min10121065

18. Renu, Madhu Agarwal, Singh K., 2017. Heavy metal removal from wastewater using various adsorbents: a review. Journal of Water Reuse and Desalination. 7 (4), 387-419. doi: doi.org/10.2166/wrd.2016.104

19. Rhodes J. C. 2010. Properties and applications of zeolites. Science Progress, 93(3), 1-63. doi: 10.31 84/003685010X12800828155007
20. Rogov V.M., Regusz A.Ya., Tichonowa I.A. 2009. Особливості адсорбційних іонів важких металів iз стічних вод природним клиноптилолітом. Вісн. Нац. ун-ту «Львів. Політехніка». № 655. C. $242-249$

21. Sekomo C.B., Rousseau D.P.L., Lens P.N.L. 2012. Use of Gisenyi Volcanic Rock for Adsorptive Removal of $\mathrm{Cd}(\mathrm{II}), \mathrm{Cu}(\mathrm{II}), \mathrm{Pb}(\mathrm{II})$, and $\mathrm{Zn}$ (II) from Wastewater. Water Air Soil Pollut 223, 533-547. doi.org/10.1007/s11270-011-0880-Z

22. Sen Gupta S., Bhattacharyya KG. 2011. Kinetics of adsorption of metal ions on inorganic materials: A review. Adv. Colloid Interface Sci. 162(1-2), 39-58. doi:10.1016/j.cis.2010.12.004

23. Shuibo X., Chun Z., Xinghuo Z., Jing Y., Xiaojian Z., Jingsong W. 2009. Removal of uranium(VI) from aqueous solution by adsorption of hematite. Journal of Environmental Radioactivity 100, 162 166. doi:10.1016/j.jenvrad.2008.09.008

24. Taffarel S.R., Rubio J. 2010. Removal of $\mathrm{Mn}^{2+}$ from aqueous solution by manganese oxide coated zeolite. Minerals Engineering, 23, 1131-1138. doi:10.1016/j.mineng.2010.07.007

25. Tekerlekopoulou A.G., Pavlou S., Vayenas D.V. 2013. Removal of ammonium, iron and manganese from potable water in biofiltration units: A review. J. Chem. Technol. Biotechnol. 88, 751-773. doi:10.1002/jctb.4031.

26. Treybal R.E. 1981. Mass Transfer Operations, McGraw-Hill, New York.

27. Ugwu M. I., Igbokwe A. O., 2019. Sorption of Heavy Metals on Clay Minerals and Oxides: A Review. In Advanced Sorption Process Applications; Edebali S. Ed., IntechOpen. doi: 10.5772/intechopen.80989

28. Vries D., Bertelkamp C., Schoonenberg Kegel F., Hofs B., Dusseldorp J., Bruins J.H., de Vet W., van den Akker B. 2017. Iron and manganese removal: Recent advances in modelling treatment efficiency by rapid sand filtration. Water Res. 109, 35-45. doi:10.1016/j.watres.2016.11.032

29. Zhou C. H., Zhou Q., Wu Q. Q., Petit S., Jiang X. C., Xia S. T., Li C. S., Yu W. H. 2019. Modification, hybridization and applications of saponite: An overview. Applied Clay Science 168, 136-154. doi. org/10.1016/j.clay.2018.11.002 